\title{
Productive and chemical characteristics of Marandu grass in response to poultry manure and soil chiseling
}

\author{
Edson S. Eguchi ${ }^{1}$, Ulysses Cecato ${ }^{2}$, Antonio S. Muniz ${ }^{3}$, Carlos A. L. de Oliveira ${ }^{2}$, \\ Raphael A. C. Murano ${ }^{4} \&$ Maria A. P. Pierangeli ${ }^{1}$ \\ ${ }^{1}$ Departamento de Zootecnia/Universidade do Estado de Mato Grosso. Pontes e Lacerda, MT. E-mail: eguchi@unemat.br (Corresponding author); \\ mapp@unemat.br \\ ${ }^{2}$ Departamento de Zootecnia/Universidade Estadual de Maringá. Maringá, PR. E-mail: ulyssescecato@gmail.com; caloliveira@uem.br \\ ${ }^{3}$ Departamento de Agronomia/Universidade Estadual de Maringá, PR. E-mail: asmuniz@uem.br \\ ${ }^{4}$ Graduando em Agronomia/Bolsista PIBITI/Universidade Estadual de Maringá, PR. E-mail:rapha_murano@hotmail.com
}

Key words:

fertilization

Brachiaria

management

nutrient

sustainability

\begin{abstract}
A B S T R A C T
The objective of this study was to evaluate the productive and chemical characteristics of Marandu grass fertilized with poultry manure with or without the use of soil chiseling, during a period of 210 days. The experiment was conducted in a Dark-Red Latosol (Haplustox) of sandy texture, in a randomized block design with 4 replicates, in a $6 \times 2$ factorial scheme $\left(0,1.037,2.074,4.148,6.222 \mathrm{t} \mathrm{ha}^{-1}\right.$ of poultry manure and an additional treatment with chemical fertilizer based on $2.074 \mathrm{t} \mathrm{ha}^{-1}$, with and without soil chiseling). Grass-cutting management was performed between $95 \%$ of light interception by the canopy and the residual height of $0.15 \mathrm{~m}$. The application of poultry manure resulted in an increase of forage production with higher number of cuts (NC). A linear model described the effect of the applied manure doses on dry matter accumulation (DMA), stems + sheaths (SS) and dead material (DM). There was significant interaction between manure doses and soil managements for leaf blade (LB), with greater variations in the treatment without soil chiseling. For plant chemical evaluation, a negative effect of poultry manure was observed on the contents of $\mathrm{Ca}, \mathrm{Mg}, \mathrm{N}, \mathrm{S}, \mathrm{Mn}$ and $\mathrm{Zn}$, which may be due to the increased number of cuts. Poultry manure positively changed the production of Marandu grass.
\end{abstract}

\section{Palavras-chave: adubação Brachiaria manejo nutriente} sustentabilidade

\section{Características produtivas e químicas do capim Marandu em função de esterco de galinha e escarificação}

\section{R E S U M O}

Objetivou-se, com este trabalho, avaliar as características produtivas e químicas do capim Marandu fertilizado com esterco de galinha com ou sem uso de escarificador, no período de 210 dias. O experimento foi realizado em Latossolo Vermelho distrófico de textura arenosa utilizando-se o delineamento em blocos casualizados com 4 repetições em esquema fatorial $6 \times 2(0 ; 1,037 ; 2,074 ; 4,148 ; 6,222) \mathrm{t} \mathrm{ha}^{-1}$ de esterco e tratamento adicional com adubação química baseado em 2,074 tha ${ }^{-1}$, sem e com escarificação. O manejo de corte do capim foi realizado entre a interceptação luminosa de $95 \%$ do dossel e a altura de resíduo, de 0,15 m. O esterco de galinha proporcionou o aumento na produção de forragem com o aumento de número de cortes (NC). Com o modelo linear a quantidade do esterco aplicado é refletida na massa seca acumulada (MS), colmo + bainha (CB) e material morto (MM). Constatouse interação entre doses de esterco e o manejo edáfico para lâmina foliar acumulada (LF), com maiores variações sem escarificação do solo. $\mathrm{Na}$ avaliação química da planta houve redução nos teores de $\mathrm{Ca}, \mathrm{Mg}, \mathrm{N}, \mathrm{S}, \mathrm{Mn}$ e $\mathrm{Zn}$, com aumento de dose de esterco de galinha talvez pelo aumento no número de cortes. O esterco de galinha alterou de forma positiva a produção do capim Marandu. 


\section{INTRODUCTION}

Pastures established in low-fertility soils, usually without adequate management, soil correction and fertilization, produce forages with low nutritional value, characterized by high contents of cell-wall constituents and by low contents of protein, calcium and phosphorus (Santos et al., 2008).

Soil fertility, plant physiological age at the moment of grazing or cutting and management strategies can result in variations of the canopy structure that influence animal development as a consequence of the amount and nutritional value of the forage offered and consumed. According to Pedreira et al. (2009), the best strategy for the defoliation of Xaraés grass is $95 \%$ of light interception with residual height of $0.15 \mathrm{~m}$ for leaf accumulation.

Nutrient mineralization through the decomposition of solid organic residues applied to soil is a complex and slow process (Moreira \& Siqueira, 2006). According to Kiehl (1985), poultry manure is an important organic fertilizer, since it concentrates nutrients in higher amounts, because of the high-protein animal feed.

For a sustainable agriculture, many management systems with mechanical fertilization can be studied aiming to maintain soil fertility (Moreti et al., 2007). The use of chisel plows in degraded pasture areas can break the compacted superficial layer of the soil and, in a certain way, incorporate poultry manure in the pasture, according to the recommendations of Brasil (2009).

In this context, the objective of this study was to evaluate productive and chemical characteristics of Marandu grass (Brachiaria) fertilized with organic residue of poultry manure and managed with or without soil chiseling.

\section{Material AND Methods}

The experiment was carried out in the Iguatemi Experimental Farm (232 $25^{\prime}$ S; 515’ W; 550 m), at the Maringá State University (UEM), Maringá-PR, Brazil. The experiment began in September 2012, in an area under Marandu grass with 10 years of grazing in a distrophic Red Latosol (EMBRAPA, 2013 ) with sandy texture, with $87.25 \%$ of sand, $1.00 \%$ of silt and $11.75 \%$ of clay. The results of the soil chemical analysis at 0.20 $\mathrm{m}$ of depth were: $\mathrm{C}=8.23 \mathrm{~g} \mathrm{dm}^{-3} ; \mathrm{P}=6.28 \mathrm{mg} \mathrm{dm}^{-3} ; \mathrm{H}^{+}+\mathrm{Al}^{+3}$ $=2.54 \mathrm{cmol}_{\mathrm{c}} \mathrm{dm}^{-3} ; \mathrm{Ca}^{+2}=0.87 \mathrm{cmol}_{\mathrm{c}} \mathrm{dm}^{-3} ; \mathrm{Mg}^{+2}=0.57 \mathrm{cmol}_{\mathrm{c}}$ $\mathrm{dm}^{-3} ; \mathrm{K}^{+}=0.13 \mathrm{cmol}_{\mathrm{c}} \mathrm{dm}^{-3}$ and $\mathrm{pH}\left(\mathrm{H}_{2} \mathrm{O}\right)=6$.

The analysis of poultry manure showed the following results: Organic Matter $=60 \%, \mathrm{~N}_{\text {total }}=6.64 \%, \mathrm{CaO}=3.53 \%$, $\mathrm{MgO}=5.51 \%, \mathrm{~K}_{2} \mathrm{O}=3.71 \%, \mathrm{P}_{2} \mathrm{O}_{5}=2.41 \%, \mathrm{C} / \mathrm{N}=4.96: 1, \mathrm{Cu}$ $=220.1 \mathrm{mg} \mathrm{kg}^{-1} ; \mathrm{Mn}=1226.9 \mathrm{mg} \mathrm{kg}^{-1} ; \mathrm{Zn}=368 \mathrm{mg} \mathrm{kg}^{-1}$ and $\mathrm{pH}\left(\mathrm{H}_{2} \mathrm{O}\right)=6.98$.

In order to increase soil base saturation by $50 \%$, liming was performed using $490 \mathrm{~kg} \mathrm{ha}^{-1}$ of dolomitic limestone, in August. After 25 days, a leveling cut was performed in the Marandu grass, using a mower at the height of $0.10 \mathrm{~m}$. The experiment was set in a randomized block design with 4 replicates, in a $6 \mathrm{x}$ 2 factorial scheme (Manure doses of 0, 1.037, 2.074, 4.148 and $6.222 \mathrm{t} \mathrm{ha}^{-1}+$ additional chemical treatment, with or without soil chiseling. In the additional chemical treatment, $138 \mathrm{~kg} \mathrm{ha}^{-1}$ of
$\mathrm{N}_{\text {total }}, 50 \mathrm{~kg}$ of $\mathrm{P}_{2} \mathrm{O}_{5}$ and $77 \mathrm{~kg} \mathrm{ha}^{-1}$ of $\mathrm{K}_{2} \mathrm{O}$ were added, equivalent to the treatment with $2.074 \mathrm{t} \mathrm{ha}^{-1}$ (Oliveira, 2003).

In September, precipitation of about $75 \mathrm{~mm}$ occurred in the area (Figure 1). Poultry manure and $270 \mathrm{~kg} \mathrm{ha}^{-1}$ of agricultural gypsum were manually applied in each experimental unit $(6 \mathrm{x}$ $4 \mathrm{~m}$ ). The additional chemical treatment was applied every 60 days and consisted of $50 \mathrm{~kg} \mathrm{ha}^{-1}$ of $\mathrm{P}_{2} \mathrm{O}_{5}$ (triple superphosphate), $1 / 3$ of the dose of $\mathrm{N}_{\text {total }}$ (ammonium nitrate) and $1 / 3$ of $\mathrm{K}_{2} \mathrm{O}$ (potassium chloride). Then, soil chiseling was performed in the respective plots, at the depth of $0.2 \mathrm{~m}$, using a small chisel plow (IKEDA, model DPT320M).

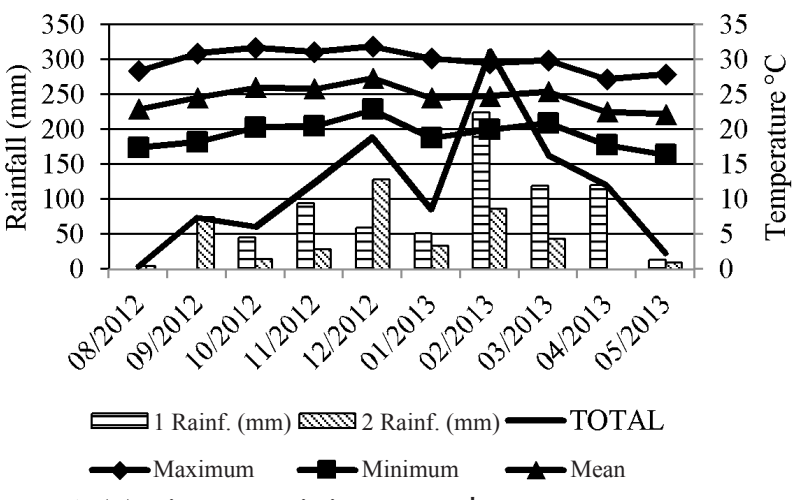

Figure 1. Maximum, minimum and mean temperatures and biweekly rainfalls during the experiment in the Iguatemi Experimental Farm

The management of the Marandu grass was based on the canopy light interception (LI) of 95\%, measured with a device (AccuPAR model LP-80 PAR/LAI Ceptometer) with weekly readings, and cuts using a mechanical mower at the residual height of $0.15 \mathrm{~m}$. For the determination of dry matter accumulation $\left(\mathrm{Mg} \mathrm{ha}^{-1}\right)$ for the period of 210 days, a steel square with area of $0.25 \mathrm{~m}^{2}(0.50 \times 0.50 \mathrm{~m})$ was used and two samples at the soil surface with $95 \%$ LI. Then, the grass was mechanically mowed at the height of $0.15 \mathrm{~m}$, with removal of all the cut material. All the material was placed in paper bags and weighed in the laboratory. For dry matter accumulation (DMA), a subsample was placed in an identified paper bag and weighed. In another subsample, the morphological components were manually separated: leaf blade (LB), stem + sheath (SS) and dead material (DM). All the dry matter and the fractions were weighed and put in a forced-air oven at 55 ${ }^{\circ} \mathrm{C}$ for $72 \mathrm{~h}$, until constant mass, for later determination of the respective masses.

The chemical composition of the Marandu grass was determined at the end of the period, with 95\% LI and grass cut at soil level. Samples were collected, weighed, dried in an oven, ground in a Willey mill using a $1 \mathrm{~mm}$ grid sieve and taken to the Agrochemistry and Environment Laboratory (UEM). The following elements were determined: magnesium $(\mathrm{Mg})$, calcium $(\mathrm{Ca})$, potassium $(\mathrm{K})$, copper $(\mathrm{Cu})$, manganese $(\mathrm{Mn})$ and zinc $(\mathrm{Zn})$ (atomic absorption spectrometry, in digest obtained by nitric-perchloric acid), total phosphorus (P) and sulfur (S) (UV-Vis spectrophotometry, in digest obtained by nitric-perchloric acid) and total nitrogen (N) (conventional Kjeldahl method)

The data were subjected to analysis of variance, Tukey test $(\mathrm{p}<0.05)$ and the regression analysis for the significant effects 
by t-test $(\mathrm{p}<0.05)$ of linear and quadratic models, using the R software (R Development Core Team, 2009).

\section{Results AND Discussion}

Poultry manure doses promoted significant changes $(\mathrm{p}<$ $0.05)$ in the number of cuts (NC), dry matter accumulation (DMA), stem + sheath (SS), dead material (DM), magnesium $(\mathrm{Mg})$, calcium $(\mathrm{Ca})$, potassium $(\mathrm{K})$, phosphorus $(\mathrm{P})$, manganese $(\mathrm{Mn})$ and zinc $(\mathrm{Zn})$. No effect was observed on leaf blade (LB), nitrogen $(N)$, sulfur $(S)$ and copper $(\mathrm{Cu})$, for which there was interaction of manure dose and soil management (Table 1).

The number of cuts (NC) of Marandu grass increased with the poultry manure fertilization, and the data adjusted to the linear model. A NC of 1.89 was found for the dose of 0 $\mathrm{t} \mathrm{ha}^{-1}$, and 5.5 for the highest manure dose, based on 95\% LI (Figure 2A).

The highest NC values were influenced by the higher mineralization of macro and micronutrients present in the highest doses of poultry manure, which were made available to the Marandu grass. These values agree with the ones of Lima et al. (2007) and provide favorable chemical conditions in soil for the development of the pasture.

The adjustment to the linear model allows higher pasture use under this management condition for the highest manure dose, specifically because of $\mathrm{N}$, a macronutrient present in higher amounts in the chemical composition of the poultry manure, which promotes positive changes like renewal of tillers and development of leaves in Marandu grass.

For the chemical treatment, despite the equivalence with the dose of $2.074 \mathrm{t} \mathrm{ha}^{-1}$ of poultry manure, the NC was similar to the treatments with the highest poultry manure doses (Table
1 and Figure 2A). The period of application and the division into $1 / 3$ of $\mathrm{N}$ and $\mathrm{K}$ doses contributed to the increase in $\mathrm{NC}$, with higher solubility and availability of macronutrients from the mineral fertilization to the Marandu grass.

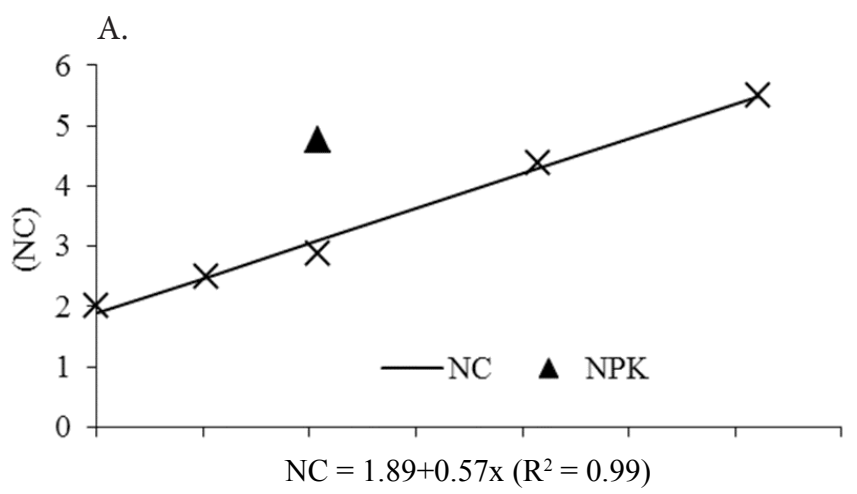

B.

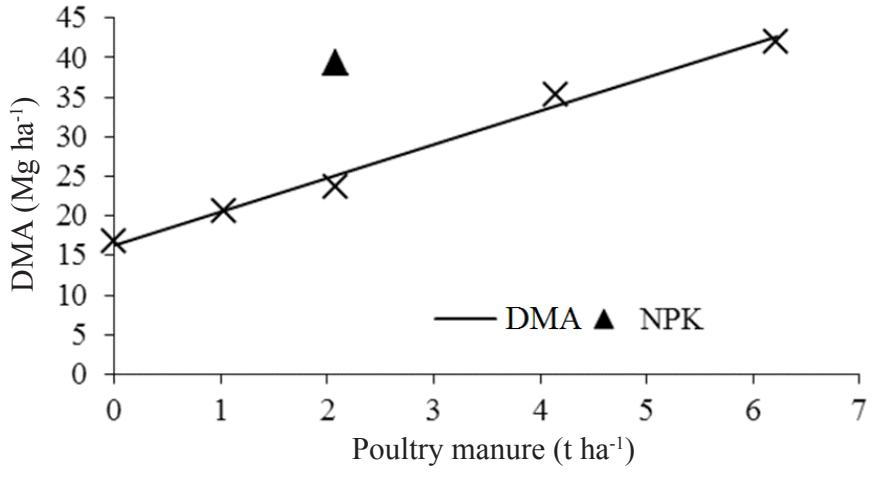

$\mathrm{DMA}=16.35+4.21 \times\left(\mathrm{R}^{2}=0.98\right)$

Figure 2. Number of cuts (NC) (A) and dry matter accumulation (DMA) (B), with light interception of $95 \%$ in Marandu grass fertilized with poultry manure and a mineral source (NPK)

Table 1. Summary of the analysis of variance and comparison of means for number of cuts (NC), dry matter accumulation (DMA), stem + sheath (SS), dead material (DM), and contents of magnesium (Mg), calcium (Ca), potassium (K), phosphorus $(\mathrm{P})$, nitrogen $(\mathrm{N})$, sulfur $(\mathrm{S})$, copper $(\mathrm{Cu})$, manganese $(\mathrm{Mn})$ and zinc $(\mathrm{Zn})$ of Marandu grass

\begin{tabular}{|c|c|c|c|c|c|c|c|c|c|c|c|c|}
\hline & \multicolumn{3}{|c|}{ Mean squares } & \multirow{2}{*}{ Re } & \multirow{2}{*}{$\begin{array}{l}\text { CV } \\
\text { (\%) }\end{array}$} & \multicolumn{5}{|c|}{ Manure dose $\left(\mathrm{t} \mathrm{ha}^{-1}\right)$} & \multirow{2}{*}{ NPK } & \multirow{2}{*}{ MSE } \\
\hline & Dose (D) & Manag. (M) & $D \times M$ & & & 0 & 1.037 & 2.074 & 4.148 & 6.222 & & \\
\hline NC & $15.68^{*}$ & 0.33 & 1.28 & 0.70 & 22.85 & $2.00 \mathrm{a}$ & $2.50 \mathrm{a}$ & $2.87 \mathrm{a}$ & $4.37 \mathrm{~b}$ & $5.50 \mathrm{~b}$ & $4.75 b$ & 0.29 \\
\hline DMA & $893.66^{*}$ & 54.48 & 67.28 & 41.49 & 21.73 & $16.87 \mathrm{a}$ & $20.58 \mathrm{a}$ & $23.74 \mathrm{a}$ & $35.38 b$ & $42.02 \mathrm{~b}$ & $39.24 \mathrm{~b}$ & 2.27 \\
\hline \multirow{2}{*}{$\begin{array}{c}\text { (nSc) } \\
\text { LB } \\
\text { (wSC) }\end{array}$} & \multirow{2}{*}{222.01} & \multirow{2}{*}{2.64} & \multirow{2}{*}{$16.82^{\star}$} & \multirow{2}{*}{6.76} & \multirow{2}{*}{20.74} & $5.70 \mathrm{a}$ & $7.61 \mathrm{a}$ & $7.98 \mathrm{a}$ & $15.77 b$ & $20.48 \mathrm{~b}$ & $19.04 b$ & 1.30 \\
\hline & & & & & & $6.06 \mathrm{a}$ & $8.51 \mathrm{ab}$ & $12.06 \mathrm{ab}$ & $14.61 \mathrm{c}$ & $17.04 \mathrm{c}$ & $15.48 \mathrm{c}$ & 1.30 \\
\hline CB & $103.77^{*}$ & 8.63 & 6.42 & 4.01 & 21.25 & $5.27 \mathrm{a}$ & $6.12 \mathrm{a}$ & $7.43 a$ & $11.39 \mathrm{~b}$ & $13.7 b$ & $12.68 \mathrm{~b}$ & 0.70 \\
\hline MM & $23.79^{\star}$ & 7.97 & 3.3 & 6.13 & 32.29 & $5.71 \mathrm{a}$ & $6.39 a b$ & $6.28 a b$ & $8.79 a b$ & $9.56 \mathrm{~b}$ & $9.30 a b$ & 0.87 \\
\hline $\mathrm{Mg}$ & $2.51^{\star}$ & 0.00 & 0.13 & 0.26 & 15.24 & $3.77 b c$ & $3.48 \mathrm{ab}$ & $3.01 \mathrm{ab}$ & $2.87 \mathrm{a}$ & $2.96 \mathrm{a}$ & $4.30 \mathrm{C}$ & 0.18 \\
\hline $\mathrm{Ca}$ & $43.06^{\star}$ & 8.37 & 17.6 & 0.42 & 11.75 & $6.14 \mathrm{~b}$ & $6.72 \mathrm{~b}$ & $4.00 \mathrm{a}$ & $3.25 \mathrm{a}$ & $3.68 \mathrm{a}$ & $9.30 \mathrm{c}$ & 0.22 \\
\hline $\mathrm{K}$ & $4.33^{\star}$ & 0.96 & 2.73 & 1.16 & 13.73 & $6.72 \mathrm{a}$ & $7.83 \mathrm{ab}$ & $7.92 b$ & $8.04 \mathrm{ab}$ & $8.99 b$ & $7.56 \mathrm{ab}$ & 0.38 \\
\hline $\mathrm{P}$ & $2.46^{\star}$ & 0.00 & 0.23 & 0.13 & 8.62 & $3.76 \mathrm{ab}$ & $4.14 \mathrm{bc}$ & $4.68 \mathrm{~cd}$ & $4.95 \mathrm{~d}$ & $4.30 \mathrm{bc}$ & $3.46 \mathrm{a}$ & 0.12 \\
\hline \multirow{2}{*}{$\begin{array}{c}\text { (nSc) } \\
N \\
\text { (WSC) }\end{array}$} & \multirow{2}{*}{20.64} & \multirow{2}{*}{0.07} & \multirow{2}{*}{$30.61^{*}$} & \multirow{2}{*}{11.00} & \multirow{2}{*}{16.12} & $23.30 \mathrm{a}$ & $22.47 \mathrm{a}$ & $21.95 \mathrm{a}$ & $17.36 \mathrm{a}$ & $18.73 a$ & $19.90 \mathrm{a}$ & 1.65 \\
\hline & & & & & & $19.26 a b$ & $22.93 \mathrm{ab}$ & $17.08 \mathrm{a}$ & $19.08 a b$ & $24.48 \mathrm{~b}$ & $20.41 a b$ & 1.65 \\
\hline \multirow{2}{*}{$\begin{array}{c}\text { (nSC) } \\
\text { S } \\
\text { (WSC) }\end{array}$} & \multirow{2}{*}{0.04} & \multirow{2}{*}{0.03} & \multirow{2}{*}{$0.09^{*}$} & \multirow{2}{*}{0.02} & \multirow{2}{*}{30.77} & $0.46 \mathrm{ab}$ & $0.38 \mathrm{a}$ & $0.78 \mathrm{~b}$ & $0.44 \mathrm{ab}$ & $0.47 \mathrm{ab}$ & $0.60 \mathrm{ab}$ & 0.08 \\
\hline & & & & & & $0.72 \mathrm{a}$ & $0.70 \mathrm{a}$ & $0.54 \mathrm{a}$ & $0.56 \mathrm{a}$ & $0.44 \mathrm{a}$ & $0.48 \mathrm{a}$ & 0.08 \\
\hline \multirow{2}{*}{$\begin{array}{c}\text { (nsc) } \\
\mathrm{Cu} \\
\text { (wSC) }\end{array}$} & \multirow{2}{*}{749.94} & \multirow{2}{*}{22.41} & \multirow{2}{*}{$99.27^{*}$} & \multirow{2}{*}{17.98} & \multirow{2}{*}{34.71} & $7.20 \mathrm{a}$ & $1.65 \mathrm{a}$ & $2.32 \mathrm{a}$ & $26.27 \mathrm{~b}$ & $26.20 \mathrm{~b}$ & $5.55 b$ & 2.12 \\
\hline & & & & & & $4.55 \mathrm{a}$ & 7.77 ab & $15.02 b c$ & $26.52 \mathrm{~d}$ & $18.95 \mathrm{~cd}$ & $4.57 \mathrm{a}$ & 2.12 \\
\hline $\mathrm{Mn}$ & $8504.52^{*}$ & 311.1 & 781.82 & 698.45 & 19.57 & $176.58 d$ & $143.98 \mathrm{bcd}$ & 132.81 bc & $105.17 \mathrm{ab}$ & $90.87 \mathrm{a}$ & $160.76 \mathrm{~cd}$ & 9.34 \\
\hline $\mathrm{Zn}$ & $134.32^{*}$ & 4.32 & 50.81 & 22.13 & 12.61 & $31.72 \mathrm{a}$ & $44.30 \mathrm{~b}$ & $36.46 \mathrm{a}$ & $35.82 \mathrm{a}$ & $38.30 \mathrm{ab}$ & $37.28 \mathrm{ab}$ & 1.66 \\
\hline
\end{tabular}

CV - Coefficient of variation; Re - Residue; Manag. - Management; MSE - Mean standard error; NPK - Mineral source; * Significant ( $p$ < 0.05); Means followed by the same letters in the row do not differ by Tukey test ( $p>0.05$ ); nsc - Management with no soil chiseling; wsc - Management with soil chiseling 
The growth of Marandu grass varied significantly with the poultry manure doses (Figure 2B), adjusting to the linear model, which was shown by the dry matter accumulation (DMA) with 95\% LI. For the control treatment without fertilization, the increment was $26.22 \mathrm{Mg} \mathrm{ha}^{-1}$. Besides the dependence on quality and quantity of the applied manure, Silva et al. (2012) attribute the increase of Marandu grass productivity to the release of nutrients by the poultry manure throughout the production cycle.

Silva et al. (2012) observed linear adjustment and DMA of 21.316 $\mathrm{Mg} \mathrm{ha}^{-1}$ for the dose of $20 \mathrm{tha}^{-1}$ of poultry litter. Silva et al. (2013) found a quadratic adjustment and a mean value of $6.48 \mathrm{Mg} \mathrm{ha}^{-1}$ for the DMA of Marandu grass at 95 days, with the application of $5 \mathrm{t} \mathrm{ha}^{-1}$ of poultry manure. For Lana et al. (2010), the highest DMA value was $5.41 \mathrm{Mg} \mathrm{ha}^{-1}$ for the dose of $9.37 \mathrm{t} \mathrm{ha}^{-1}$ of poultry litter, in the second cut of Brachiaria decumbens shoots, at 60 days after the imposition of treatments.

The DMA of $39.24 \mathrm{Mg} \mathrm{ha}^{-1}$ observed for the treatment with chemical fertilization (NPK) is similar to the one for the treatment with the highest poultry manure doses (Table 1). Lima et al. (2007) observed DMA increases of 33.4 and $96.6 \%$ for the doses of 15 and $20 \mathrm{t} \mathrm{ha}^{-1}$ of poultry litter, respectively, compared with the chemical fertilization using $100 \mathrm{~kg} \mathrm{ha}^{-1}$ of $\mathrm{N}$.

The leaf blades (LB), with interaction of the poultry manure fertilization and soil management, adjusted to the linear model (Figure 3A). LB increased to $15.49 \mathrm{Mg} \mathrm{ha}^{-1}$ without soil chiseling (LBnsc) and to $10.80 \mathrm{Mg} \mathrm{ha}^{-1}$ with soil chiseling
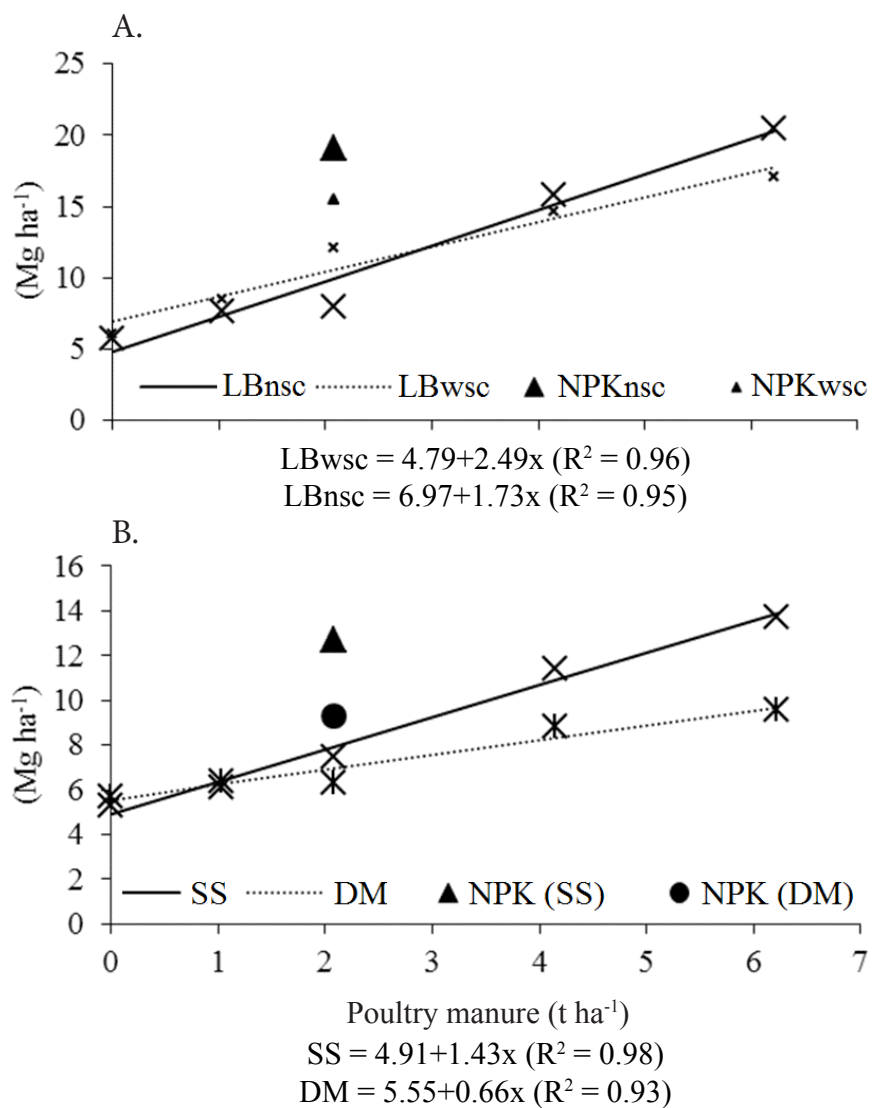

Figure 3. Leaf blades (LB) (A), stem + sheath (SS) (B) and dead material (DM) (B) with $95 \%$ of light interception in Marandu grass fertilized with poultry manure and a mineral source (NPK) under management with (WSC) and without (nsc) soil chiseling
(LBwsc); the former was $43.42 \%$ higher than the latter (Figure $3 \mathrm{~A})$. Chisel plowing can have caused the breaking of grass roots, causing a longer period of LI recovery for the doses of 0 and $1.037 \mathrm{t} \mathrm{ha}^{-1}$ of poultry manure.

Both LBnsc and LBwsc increased with the increase in fertilization, but LBwsc was higher than LBnsc by $2.18 \mathrm{Mg}$ $\mathrm{ha}^{-1}$, for the manure dose of $0 \mathrm{t} \mathrm{ha}^{-1}$. The increase of 0.04 $\mathrm{m} \mathrm{m}^{-3}$ in macroporosity for the layer of $0-0.20 \mathrm{~m}$, for the management with soil chiseling, contributed to an additional mineralization of the nutrients, which increased leaf production in this treatment. As for the doses higher than $2.86 \mathrm{t} \mathrm{ha}^{-1}$, the improvements in the physical conditions with soil chiseling were lower compared with the situation without this management.

LBwsc was higher than LBnsc for the NPK treatment, but similar for the doses of 4.148 and $6.222 \mathrm{t} \mathrm{ha}^{-1}$ of poultry manure (Table 1).

The increase in stem + sheath (SS) with 95\% LI was influenced by the increment in the fertilization with poultry manure (Figure 3B). For the highest dose, SS increased by $159 \%$ compared with no manure application. The increase in SS is justified by the higher number of tillers and the frequency of cuts performed.

The accumulated mass of dead material (DM) with 95\% LI also increased with the poultry manure fertilization, with variation of $4.12 \mathrm{Mg} \mathrm{ha}^{-1}$ (Figure 3B). The variation of $0.64 \mathrm{Mg}$ $\mathrm{ha}^{-1}$ observed for DM is higher than SS for the treatment with no manure application, which confirms the structural changes in Marandu grass due to the nutritional contribution from the soil with increasing doses of poultry manure. According to Pedreira et al. (2009), reduction in the availability factors for pasture development increases the time necessary for the pasture to reach $95 \% \mathrm{LI}$, causing the accumulation of stems and senescence to increase in this competition for light.

In the chemical evaluation of Marandu grass shoots with 95\% LI, the magnesium content $(\mathrm{Mg})$ was affected by poultry manure application and adjusted to the quadratic model (Figure 4A). The lowest $\mathrm{Mg}$ content $\left(2.83 \mathrm{~g} \mathrm{~kg}^{-1}\right)$ was observed for the manure dose of $4.48 \mathrm{t} \mathrm{ha}^{-1}$. For Werner et al. (1997), the concentrations considered ideal for Brachiaria brizantha range from 1.5 to $4.0 \mathrm{~g} \mathrm{~kg}^{-1}$. The results corroborate Silva et al. (2013), who observed linear regression and reduction of $\mathrm{Mg}$ contents with the increase in the treatments, and mean value of $2.87 \mathrm{~g} \mathrm{~kg}^{-1}$ at 95 days after fertilization with manure of laying hens in Marandu grass.

The contents of calcium $(\mathrm{Ca})$ in Marandu grass adjusted to the quadratic model and the minimum value $\left(3.38 \mathrm{~g} \mathrm{~kg}^{-1}\right)$ occurred for the dose of $5.07 \mathrm{tha}^{-1}$. These Ca values agree with Werner et al. (1996), who found contents ranging from 3 to $6 \mathrm{~g}$ $\mathrm{kg}^{-1}$ in Brachiaria brizantha. Studying Marandu grass, Barnabé et al. (2007) observed increases in mean contents of Ca with the increment in the amounts of pig slurry with cut interval of 33 days. The reduction in $\mathrm{Mg}$ and Ca contents of $0.81 \mathrm{~g} \mathrm{~kg}^{-1}$ and $2.46 \mathrm{~g} \mathrm{~kg}^{-1}$, respectively, with the increase in poultry manure dose, can be attributed to the adopted management system with higher cut frequency, phytomass removal and increase in dry matter accumulation.

In the chemical treatment (NPK), $\mathrm{Mg}$ and $\mathrm{Ca}$ contents in Marandu grass shoots were higher than the ones for the 
A.

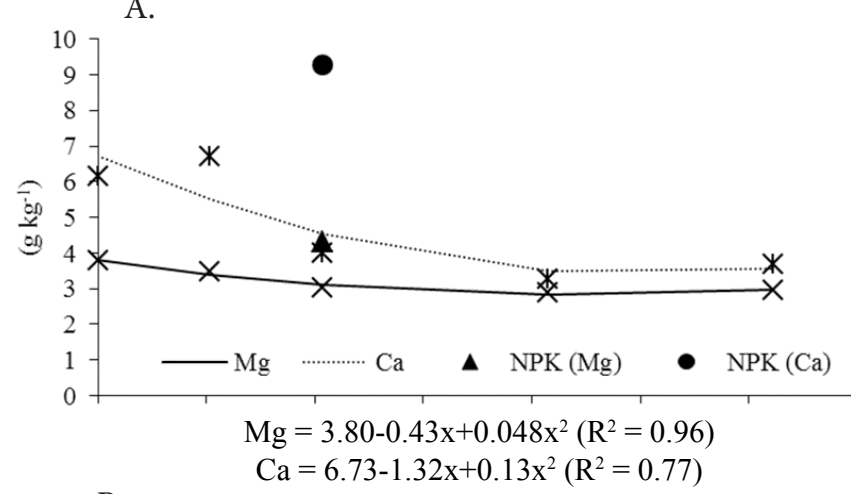

B.

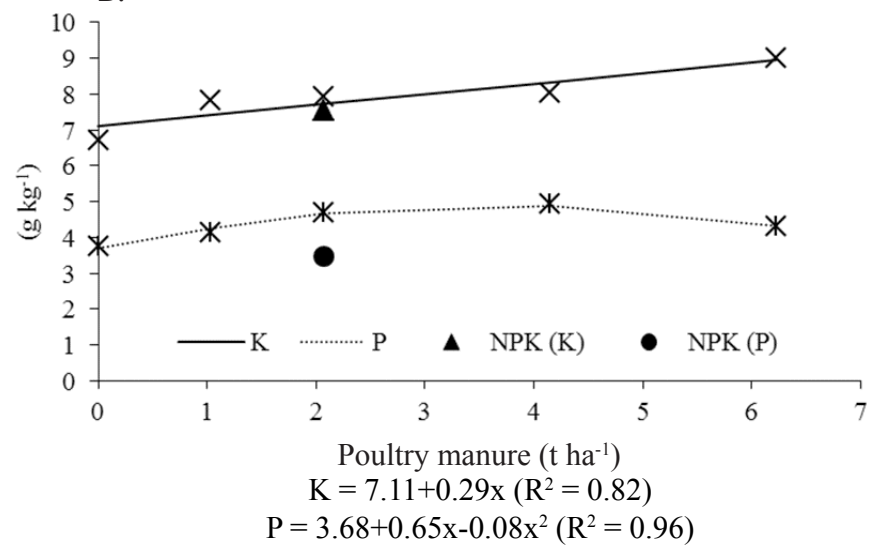

Figure 4. Contents of magnesium (Mg), calcium (Ca) (A), potassium $(\mathrm{K})$ and phosphorus $(\mathrm{P})(\mathrm{B})$ in Marandu grass shoots fertilized with poultry manure, and a mineral source (NPK) under management with (wsc) and without (nsc) soil chiseling

highest poultry manure dose, 1.33 and $5.61 \mathrm{~g} \mathrm{~kg}^{-1}$ respectively (Table 1 and Figure 4A). Lana et al. (2010) observed contents of $2.80 \mathrm{~g} \mathrm{~kg}^{-1}$ for $\mathrm{Mg}$ and $4.12 \mathrm{~g} \mathrm{~kg}^{-1}$ for Ca with mineral fertilization in the second cut, which were significant compared with highest dose of poultry manure applied. Primavesi et al. (2006) observed that Ca contents in the dry matter of Marandu grass increased, although slightly, with fertilization using ammonium nitrate.

The content of potassium $(\mathrm{K})$ adjusted to the linear model (Figure 4B) and increased with the increment in manure doses. For the highest dose $\left(6.222 \mathrm{t} \mathrm{ha}^{-1}\right)$, K content was $8.99 \mathrm{~g} \mathrm{~kg}^{-1}$, i.e., $2.27 \mathrm{~g} \mathrm{~kg}^{-1}$ higher than the control. The observed $\mathrm{K}$ contents were below the adequate range (12 to $30 \mathrm{~g} \mathrm{~kg}^{-1}$ ) for this forage, (Werner et al., 1996). These results agree with Silva Neto et al. (2010), who observed K contents below the adequate range in Marandu grass tissues, using liquid slaughterhouse effluent. Silva et al. (2013) found linear adjustment and $\mathrm{K}$ content of $17.72 \mathrm{~g} \mathrm{~kg}^{-1}$ for the treatment with $20 \mathrm{t} \mathrm{ha}^{-1}$ of poultry manure. According to Primavesi et al. (2006) and Costa et al. (2009), these low K contents may be associated with the large $\mathrm{K}$ extraction by Marandu grass with high forage production.

For the chemical treatment (NPK), the K content (7.56 g $\mathrm{kg}^{-1}$ ) was equivalent to the values for the lowest manure doses, below the adequate range for this forage (Werner et al., 1996) (Table 1). Lana et al. (2010) observed K content of $21.60 \mathrm{~g} \mathrm{~kg}^{-1}$, with no difference between mineral fertilization and poultry manure dose of $3.125 \mathrm{t} \mathrm{ha}^{-1}$ in the second cut.
Phosphorus $(\mathrm{P})$ contents adjusted to the quadratic model, with the highest value of $5.00 \mathrm{~g} \mathrm{~kg}^{-1}$ for the poultry manure dose of $4.06 \mathrm{t} \mathrm{ha}^{-1}$ (Figure 4B). P contents with manure fertilization were above the concentration range proposed by Werner et al. (1996), from 0.8 to $3.0 \mathrm{~g} \mathrm{~kg}^{-1}$. These results agree with the ones of Silva et al. (2013), who found P content of $3.0 \mathrm{~g} \mathrm{~kg}^{-1}$ for the treatment with $15 \mathrm{t} \mathrm{ha}^{-1}$ of poultry manure, which was superior to the others. Silva et al. (2012) observed P content of $0.32 \mathrm{mg} \mathrm{dm}^{-3}$ in Marandu grass tissues in rainy periods using fertilization with poultry manure.

The P content for the chemical treatment (NPK), $3.46 \mathrm{~g}$ $\mathrm{kg}^{-1}$, was lower than the values for the poultry manure doses (Table 1). Lana et al. (2010) observed P content of $2.17 \mathrm{~g} \mathrm{~kg}^{-1}$ for mineral fertilization, which was similar to the value for the poultry manure dose of $6.250 \mathrm{t} \mathrm{ha}^{-1}$.

For the interaction between manure doses and soil management, nitrogen contents without soil chiseling (Nnsc) adjusted to the linear model (Figure 5A). With the increase in the doses, $\mathrm{N}$ contents varied from 23.20 to $17.58 \mathrm{~g} \mathrm{~kg}^{-1}$, a reduction of $5.61 \mathrm{~g} \mathrm{~kg}^{-1}$. The adequate range of $\mathrm{N}$ is from 13 to $20 \mathrm{~g} \mathrm{~kg}^{-1}$ (Werner et al., 1996). Manure application contributed to maintain the concentrations of $\mathrm{N}$ in the forage without soil chiseling, but the reduction in the control treatment is related to the adopted management system. According to Silva Neto et al. (2010), with a linear model, the $\mathrm{N}$ concentration in Marandu grass shoots, in the second cut, was equal to 15.7, 16.7 and $17.8 \mathrm{~g} \mathrm{~kg}^{-1}$ for the doses of $37.5,75$ and $112.5 \mathrm{~m}^{3} \mathrm{ha}^{-1}$ of slaughterhouse liquid effluent.
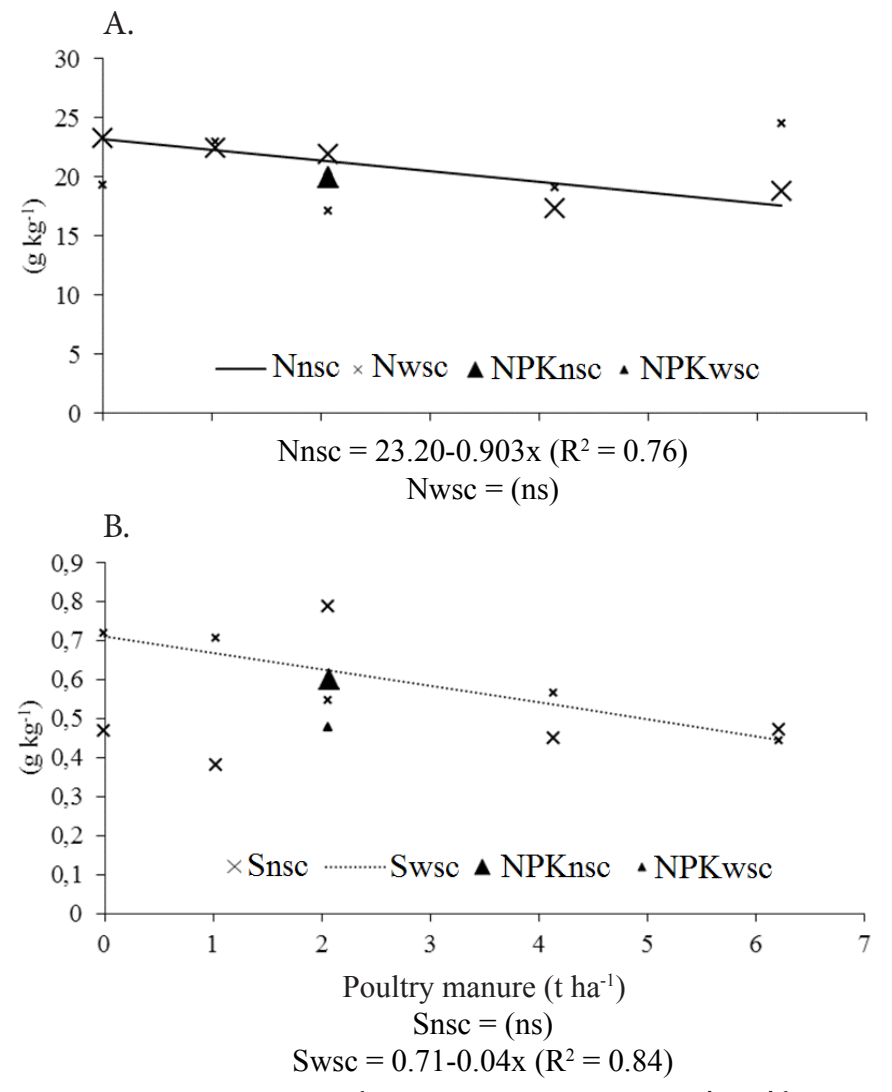

Figure 5. Contents of nitrogen (N) (A) and sulfur (S) (B) in Marandu grass shoots fertilized with poultry manure (NPKwsc) and a mineral source (NPKnsc) under management with (WSC) and without (nsc) soil chiseling 
The $\mathrm{N}$ content of $19.90 \mathrm{~g} \mathrm{~kg}^{-1}$, without soil chiseling, for the chemical treatment (NPK) is similar to all the values for the applied manure doses, which are within the adequate range for these plants (Werner et al., 1996) (Table 1).

For the interaction dose and soil management, the $S$ content with soil chiseling (Swsc) adjusted to the linear model, with reduction of $0.27 \mathrm{mg} \mathrm{kg}^{-1}$ as the poultry manure doses increased (Figure 5B). These Swsc contents are below the optimal values, according to Werner et al. (1997), which range from 1.5 to 3.0 $\mathrm{g} \mathrm{kg}^{-1}$ for the shoot dry matter of Brachiaria brizantha. The S content in Marandu grass under soil chiseling for the chemical treatment (NPK) was equal to $0.48 \mathrm{mg} \mathrm{kg}^{-1}$ and was similar to all the values for the poultry manure doses.

With respect to micronutrients, there was interaction between doses and management with soil chiseling for copper (Cuwsc) (Figure 6A). The Cuwsc contents in the forage shoots increased linearly with the increase in poultry manure doses. The maximum value observed was $18.95 \mathrm{mg} \mathrm{kg}^{-1}$, above the $\mathrm{Cu}$ concentration range referenced by Abreu et al. (2007), from 4 to $12 \mathrm{mg} \mathrm{kg}^{-1}$ for the Marandu grass. For the chemical treatment, Cuwsc content was equal to $4.57 \mathrm{mg} \mathrm{kg}^{-1}$, similar to the value for no manure application (Table 1). In the first year of evaluation, Costa et al. (2009) observed linear increase in $\mathrm{N}$ doses with increment of $42 \%$, compared with the control, with an average of three cuts in Marandu grass. Primavesi et al. (2006) verified $\mathrm{Cu}$ concentrations ranging from 7 to $10 \mathrm{mg}$ $\mathrm{kg}^{-1}$, between two nitrogen sources.

Manganese (Mn) values adjusted to the linear model and were reduced by $48.53 \%$ with the increase in poultry manure

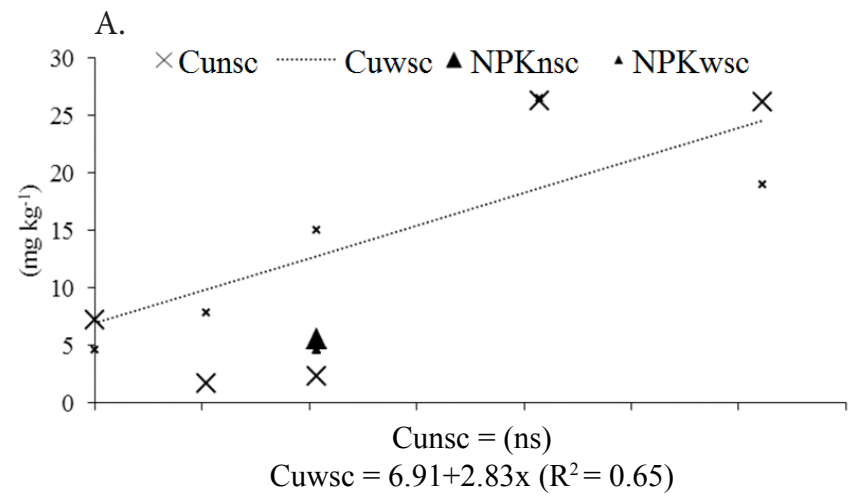

B.

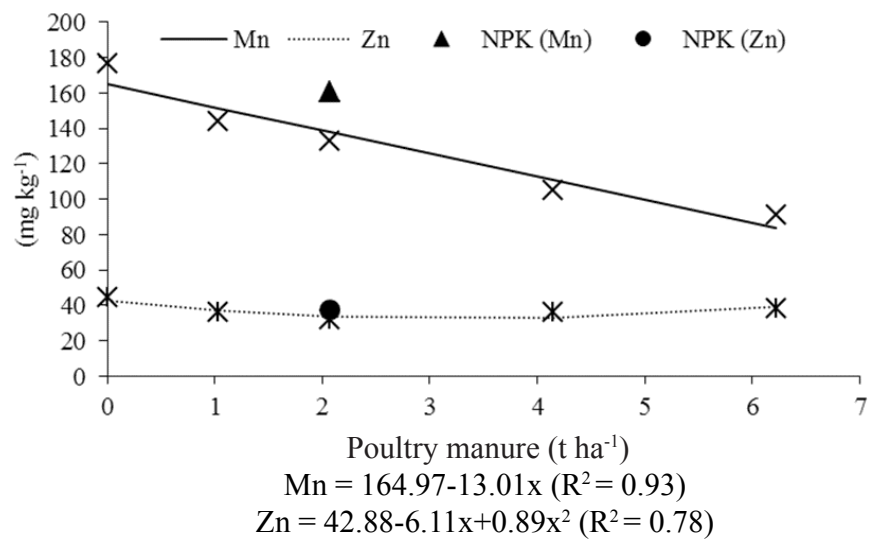

Figure 6. Contents of copper (Cu) $[\mathrm{A}]$, manganese $(\mathrm{Mn})$ and zinc $(\mathrm{Zn})[\mathrm{B}]$ in Marandu grass shoots fertilized with poultry manure (NPKwsc) and a mineral source (NPKnsc) under management with (wsc) and without (nsc) soil chiseling doses (Figure 6B). Mn contents are within the optimal range, from 40 to $250 \mathrm{mg} \mathrm{kg}^{-1}$ (Abreu et al., 2007). It is important to point out that, although the Mn content in the poultry manure was the highest one among the micronutrients, there was a reduction with the increase in manure doses. According to Guirra et al. (2011), Marandu grass shows high tolerance to $\mathrm{Mn}$ toxicity and the content of $2830 \mathrm{mg} \mathrm{kg}^{-1}$ in the shoots does not affect plant growth. In the chemical treatment (NPK), Mn content of $160.76 \mathrm{mg} \mathrm{kg}^{-1}$ (Table 1) was observed, which differed from the Mn content for the highest poultry manure dose. These results agree with Lana et al. (2010), who found Mn content of $170.5 \mathrm{mg} \mathrm{kg}^{-1}$ for mineral fertilization, higher than the values for poultry manure doses.

The content of zinc ( $\mathrm{Zn})$ adjusted to the quadratic model, with concentration of $32.39 \mathrm{mg} \mathrm{kg}^{-1}$ for the minimum dose of $3.43 \mathrm{tha}^{-1}$ in Marandu grass shoots (Figure 6B). The range was considered adequate, since $\mathrm{Zn}$ concentrations can vary from 20 to $50 \mathrm{mg} \mathrm{kg}^{-1}$, according to Abreu et al. (2007). As for the chemical treatment (NPK), the Zn content of $37.28 \mathrm{mg} \mathrm{kg}^{-1}$ was similar to the ones for the manure dose of $6.222 \mathrm{t} \mathrm{ha}^{-1}$ (Table 1). Lana et al. (2010) observed Zn content of $61.5 \mathrm{mg} \mathrm{kg}^{-1}$ for mineral fertilization, similar to the values for the doses of 3.125 and $6.259 \mathrm{t} \mathrm{ha}^{-1}$ of poultry litter.

\section{Conclusions}

1. Fertilization with poultry manure positively changes the productive characteristics of Marandu grass.

2. Poultry manure application with soil chiseling increased the production of leaves, reduced the contents of $\mathrm{S}$ and increased the contents of $\mathrm{Cu}$ in Marandu grass.

3. In the chemical evaluation of the Marandu grass shoots, the fertilization with poultry manure reduced the contents of $\mathrm{Ca}, \mathrm{Mg}, \mathrm{N}, \mathrm{Mn}$ and $\mathrm{Zn}$.

\section{Literature Cited}

Abreu, C. A.; Lopes, A. S.; Santos, G. Análise de plantas para avaliar a disponibilidade de micronutrientes. In: Novaes, R. F.; Alvarez V., V. H.; Barros, N. F.; Fontes, R. L. F.; Cantarutti, B.; Neves, J. C. L. (ed.) Fertilidade do solo. Viçosa: Sociedade Brasileira de Ciência do Solo SBCS, 1.ed. Cap. IX, 2007. p.676-680.

Barnabé, M. C.; Rosa, B.; Lopes, E. L.; Rocha, G. P.; Freitas, K. R.; Pinheiro, E. de P. Produção e composição químicobromatológica da Brachiaria brizantha cv. marandu adubada com dejetos líquidos de suínos. Ciência Animal Brasileira, v.8, p.435-446, 2007.

Brasil. Ministério da Agricultura, Pecuária e Abastecimento. Instrução Normativa n. 25, de 23 de julho de 2009. Diário Oficial da República Federativa do Brasil, Brasília, DF, 28 de julho de 2009. Seção 1, 2009, 20p. (Anexo 4).

Costa, K. A. de P.; Faquin, V.; Oliveira, I. P. de; Severiano, E. da C.; Oliveira, M. A.; Doses e fontes de nitrogênio na nutrição mineral do capim-marandu. Ciência Animal Brasileira, v.10, p.115-123, 2009.

EMBRAPA - Empresa Brasileira de Pesquisa Agropecuária. Sistema brasileiro de classificação de solos. 3.ed. Brasília: Embrapa Solos, 2013. 353p. 
Guirra, A. P. P. M.; Fiorentin, C. F.; Prado, R. de M.; Caetano, M. C. T.; Felici, A. C. Tolerância do capim Marandu a doses de manganês. Bioscience Journal, v.27, p.413-419, 2011.

Kiehl, E. J. Fertilizantes orgânicos. São Paulo: Agronômica Ceres, 1985. 492p.

Lana, R. M. Q.; Assis, D. F. de; Silva, A. de A.; Lana, A. M. Q.; Guimarães, E. C.; Borge, E. N. Alterações na produtividade e composição nutricional de uma pastagem após segundo ano de aplicação de diferentes doses de cama de frango. Bioscience Journal, v.26, p.249-256, 2010.

Lima, J. J.; Mata, J. D. V.; Neto, R. P.; Scapim, C. A. Influência da adubação orgânica nas propriedades químicas de um Latossolo Vermelho distrófico e na produção de matéria seca de Brachiaria brizantha cv. Marandu. Acta Scientiarum Agronomy, v. 29, p.715719, 2007. http://dx.doi.org/10.4025/actasciagron.v29i5.754

Moreira, F. M. S.; Siqueira, J. O. Microbiologia e bioquímica do solo. Lavras: UFLA, 2006. 729p.

Moreti, D.; Alves, M. C.; Filho, W. V. V.; Carvalho, M. P. Atributos químicos de um Latossolo Vermelho sob diferentes sistemas de preparo, adubações e plantas de cobertura. Revista Brasileira de Ciência do Solo, v.31, p.167-175, 2007. http://dx.doi.org/10.1590/ S0100-06832007000100017

Oliveira, E. L. de. Sugestão de adubação e calagem para culturas de interesse econômico no Estado do Paraná. Londrina: IAPAR, 2003. 30p.

Pedreira, B. C. e; Pedreira, C. G. S.; Silva, S. C. da. Acúmulo de forragem durante a rebrotação de capim-xaraés submetido a três estratégias de desfolhação. Revista Brasileira de Zootecnia, v.38, p.618-625, 2009. http://dx.doi.org/10.1590/S1516-35982009000400005

Primavesi, A. C.; Primavesi, O.; Corrêa, L. A.; Silva, A. G.; Cantarella, H. Nutrientes na fitomassa de capim Marandu em função de fontes e doses de nitrogênio. Ciência e Agrotecnologia, v.30, p.562-568, 2006. http://dx.doi.org/10.1590/S1413-70542006000300024
R Development Core Team. R: A language and environment for statistical computing. R Foundation for Statistical Computing (2009). Vienna, Austria. <http://www.R-project.org>. 10 Jan 2014.

Santos, L. C.; Bonomo, P.; Silva, C. C. F.; Pires, A. J. V.; Veloso, C. M.; Patês, N. M. S. Produção e composição química da Brachiaria brizantha e Brachiaria decumbens submetidas a diferentes adubações. Ciência Animal Brasileira, v.9, p.856-866, 2008.

Silva, A. A.; Simioni, G. F.; Lucena, A. Efeito da adubação orgânica no crescimento do capim Brachiaria Brizantha Cv. Marandu em Parecis/Rondônia. Enciclopédia Biosfera, v.9, p.923-932, 2013.

Silva, C. C.; Santos, A. C. dos; Silva, G. F. da; Rocha, J. M. L. da; Pires, C. C.; Oliveira, L. B. T. de. Resposta do capim Marandu (Brachiaria brizantha Stapf) a aplicação de NPK e fontes de matéria orgânica. Amazônia: Ciência \& Desenvolvimento, v.7, p.43-57, 2012.

Silva Neto, S. P. da., Silva, J. E. C. da; Santos, A. C. dos; Castro, J. G. D.; Dim, V. P.; Araújo, A. dos S. Características agronômicas e nutricionais do capim Marandu em função da aplicação de resíduo líquido de frigorífico. Acta Scientiarum. Animal Sciences, v.32, p.9-17, 2010.

Werner, J. C.; Paulino, V. T.; Cantarella, H. Forrageiras. In: Raij, B. van; Cantarella, H.; Quaggio, J. A.; Furlani, A. M. C. (ed.). Recomendações de adubação e calagem para o Estado de São Paulo. Campinas: Instituto Agronômico de Campinas, 1996. p.263-273. Boletim Técnico, 100.

Werner, J. C.; Paulino, V. T.; Cantarella, H.; Andrade, N. O.; Quaggio, J. A. Forrageiras. In: Raij, B. van; Cantarella, H.; Quaggio, J. A.; Furlani, A. M. C. Recomendações de adubação e calagem para o Estado de São Paulo. 2 ed. Campinas: Instituto Agronômico de Campinas, 1997. p.263-273. 